Boda Mihály ${ }^{1 \oplus}$

\title{
A katonai erények változása a 19. században Nyugat-Európában és Magyarországon ${ }^{2}$ \\ Change of Military Virtues in the $19^{\text {th }}$ Century in Europe and Hungary
}

\section{Absztrakt}

A hadsereg tagjainak erényei, azaz a katonai erények a társadalmi és a politikai környezet függvényei. A 19. században Európa és benne Magyarország jelentös társadalmi és politikai változásokon ment keresztül, aminek következtében a bátorság, a becsület, a hüség, a vezetöi erény és a fegyelmezettség a korábbitól eltérő tartalommal töltődött meg. A nyugat-európai és a magyar fejlödés között voltak hasonlóságok, ám a különbségek szembetünőbbek. Nyugat-Európában a hazaszereteten nyugvó bátorság, a nemzeti társadalomhoz kötődő becsület, hüség, vezetői erény és fegyelmezettség kapott nagyobb szerepet. Magyarországon viszont az istenfélelmen (és a vezetöktöl való félelmen) nyugvó bátorság, illetve a katolikus uralkodó vezette társadalomhoz kötődö becsület, hüség, vezetői erény és fegyelmezettség.

Kulcsszavak: katonai erények, bátorság, becsület, hüség, vezetői erény (karizma), fegyelmezettség

\section{Abstract}

Virtues of members of army - the military virtues - depend on the social and political environment of the army. Europe and as its part Hungary underwent huge changes in

Nemzeti Közszolgálati Egyetem Hadtudományi és Honvédtisztképző Kar Hadtörténelmi, Filozófiai és Kultúrtörténeti Tanszék, tanszékvezető egyetemi docens - University of Public Service, Faculty of Military Sciences and Officer Training Department of Military History, Philosophy, and Cultural History, Head of Department, Associate Professor, e-mail: boda.mihaly@uni-nke.hu

2 A tanulmány az Innovációs és Technológiai Minisztérium ÚNKP-20-5-NKE-25 kódszámú Új Nemzeti Kiválósági Programjának a Nemzeti Kutatási, Fejlesztési és Innovációs Alapból finanszírozott szakmai támogatásával készült. 
the $19^{\text {th }}$ century, which resulted in great changes in the content of the military virtues, like courage, honor, loyalty, charisma (virtue of military leadership), and discipline. There were similarities between the European and the Hungarian virtues, however the differences are more significant. 19th century European military virtues included courage based on love of the country, and honor, loyalty, charisma and discipline based ont he values of national society. In contrary to this, Hungarian virtues contained courage based fear from God (and from military leaders), and honor, loyalty, charisma and discipline based on values of the society ruled by the Catholic king.

Keywords: military virtues, courage, honor, loyalty, charisma, military leadership, discipline

\section{Bevezetés}

A katonai erények a katonai feladat-végrehajtásban nyújtanak segítséget a katonák számára, ezért nélkülözhetetlen részét képezik a katonákkal szemben meghatározott elvárásoknak. A katonai erények bizonyos képességek gyakorlására irányuló erkölcsi elvárások, amelyek figyelembevételéhez a képesség előzetes elsajátítása szükséges. ${ }^{3}$

A fontosabb katonai erények, a bátorság, a becsület, a hủség, a vezetői erény (karizma) és a fegyelmezettség a történelem civilizált korszakaiban nagy jelentőséggel rendelkeztek a hadseregek és a katonák számára. A katonai erények tartalma azonban az emberi élet feltételeinek, ezen belül a társadalmi és a politikai környezetnek a változásaival együtt szintén átalakuláson ment keresztül. Ilyen jelentőséggel rendelkező elmozdulás zajlott le a jelen tanulmány témájának időszakában, a 19. század folyamán is. A bürokratikus állam zsoldos hadseregét ekkor felváltotta a nemzeti állam (vagy nemzeti birodalom) állandó tömeghadserege, és kialakult a szekuláris katonai hivatás(rend). ${ }^{4}$

A katonai erények változásának bemutatásához először röviden bemutatom a katonai erények kora újkori tartalmát, majd ezt követően részletesen elemzem az erények 19. századi formáit. A változás ismertetése során kitérek a katonai erények változásának nyugat-európai és magyar vonatkozásaira is.

\section{A katonai erények a kora újkorban és az újkor elején}

A 17-18. századi katonai erények a kora újkor során előtérbe kerülő bürokratikus állam zsoldos hadserege katonáinak erényei voltak Nyugat-Európában és Magyarországon is. A kora újkori Nyugat-Európa tekintetében Niccolò Machiavelli (1469-1527) munkáiból kaphatunk képet ezekről az erényekről, Magyarország tekintetében pedig többek

Boda Mihály: Az alapvető katonai erények mibenléte és helyük a hosszú 19. századi magyar hadtudományos gondolkodásban. 1. rész. Az erények és a katonai erénylisták. Hadtudomány, 28. (2018), 1. 38-44.

4 Boda Mihály: A hivatás és a katonai hivatás története és elemei. Hadtudomány, 28. (2018), 3-4. 139-140; Boda Mihály: Az akarattól a tettig. A parancsteljesítés erkölcsi indokai. Hadtudomány, 26. (2016), 3-4. 22. 
között Magyari István (1565-1605) és Zrínyi Miklós (1620-1664) munkáiból, illetve a korszak katonai szabályzataiból. ${ }^{5}$

Machiavelli szerint a kiképzés során a szakmai tudás és a szigorú engedelmesség elsajátításából álló mesterséges bátorság a legfontosabb katonai erény, aminek gyakorlását a városállam felé mutatott hüség segíti. A parancsnoknak a katonák kiképzésében, illetve a városállam védelmében kifejtett vezetői tevékenységében szervezőképessége van segítségére. A városállam védelme akkor lehet sikeres, ha a katonák hüségesek ahhoz, illetve a parancsnok (a katonák) képességeit és nevét ellenségei és beosztottjai is félik. Ennyiben a parancsnok (minden katona) eszközjellegü erkölcsi becsülettel rendelkezik.

A katonai erények tartalma Magyari és Zrínyi munkáiban, illetve a korszak hadi szabályzataiban jelentős átfedést mutat. A mesterséges bátorság előtérbe állítása, a szigorú engedelmesség és a szervezőképességhez kötődő vezetői karizma („vigyázás”) hangsúlyozása mindkét forráscsoportra jellemző. Ami különbségként mutatható fel, az a hüség és a becsület szerepe. A hüség Zrínyinél a haza (területe) iránt mutatott hüség, ezzel szemben a hadi szabályzatokban megfogalmazott hủség általában a fejedelem és a király felé irányul. A becsület Zrínyinél főként eszközjelleggel szerepel, mint az ellenség és a saját katonák megfélemlítésének (tehát a saját haderő vezetésének) az eszköze; ezzel szemben a hadi szabályzatok szerint megbecsüléssel járó cselekedetek a hűség és a szigorú engedelmesség jegyében véghezvitt tettek, amelyek megbecsülést (nem csupán félelmet) eredményeznek, és meghatározzák a katona magában vett erkölcsi értékét (becsületét) a hadseregben.

A kora újkorban a nyugat-európai és a magyar fejlődés nagyon hasonlóan ment végbe a hadi etika területén. Az alábbiakban azt vizsgálom meg, miként zajlott le a katonai erények 19. századi paradigmaváltása.

\section{A katonai erények a 19. században Nyugat-Európában és Magyarországon}

A 19. század egész Európában a nemzeti politikai törekvések (forradalmak és egyesítési mozgalmak), illetve az ipari forradalmak kora volt, amikor a bürokratikus állam zsoldos hadseregét felváltotta a nemzeti állam állandó tömeghadserege. A politikai és a társadalmi változások ${ }^{6}$ magukkal hozták a katonai szervezetek átalakulását, és azzal együtt alakult át az azok tagjaitól és vezetőitől elvárt erények eszményeinek világa is. Változás figyelhető meg a bátorság, a becsület, a hüség, a karizma és a fegyelmezettség erényének tartalmában egyaránt. A következőkben ezen erények változását mutatom be, szem előtt tartva, hogy az erények korábbi formái korántsem tủnnek el ez időben, hanem csak jelentőségük csökken az újonnan megjelenő erényformákkal szemben.

Boda Mihály: A katonai erények paradigmaváltása a késő középkor és a kora újkor között. Hadtörténelmi Közlemények, 134. (2021), 3. 613-637.

6 Kövér Tibor - Gyáni Gábor: Magyarország társadalomtörténete a reformkortól a második világháborúig. Budapest, Osiris, 2006. 113-127. 
A bátorság, a becsület és a hüség 19. századi magyar formáival már foglalkoztam egy korábbi írásomban, ${ }^{7}$ igy ezekre most csak röviden térek ki.

\subsection{A bátorság: hazaszeretet és istenfélelem}

A katonai bátorság a háború és a csata előidézte veszélyes helyzet, illetve az azzal együtt járó kockázat és félelem kezelésének erénye, képessége. ${ }^{8}$ A kora újkorban a bátorság legfontosabb formája a mesterséges bátorság volt. A kiképzés és a gyakorlatozás során elsajátított mesterséges bátorság a veszélyes helyzet kezelésének feladatát azzal oldja meg, hogy általa a katonák megtanulják, mit kell tenniük a veszélyes helyzetben. A mesterséges bátorság így az azzal rendelkező katona számára megszünteti a helyzet veszélyességét.

Abban az esetben, amikor nincs idő a megfelelő kiképzésre és gyakorlatozásra, ám mégis szükség van a hadseregre, akkor valamilyen más módon szükséges kezelni a veszélyt. A hazaszereteten alapuló bátorság a veszélyes helyzet által a katonákban előidézett félelem érzését elnyomja egy másik, erősebb érzés, a hazaszeretet érzésének segítségével. Carl von Clausewitz (1780-1831) A háborúról című munkájában úgy vélekedik, hogy alapvetően kétféle bátorság van: a személyes bátorság, amely a veszéllyel egyénileg találkozó katona jellemzője, és a felelősségvállalás bátorsága, amely utóbbi a valaki felé való elszámolással áll kapcsolatban. A személyes bátorságnak ismét két típusa van: az egyik esetben a bátorság a közömbösség tartós állapotából ered, a másik esetben „pozitív tényezőkből: becsvágyból, hazaszeretetből vagy másfajta lelkesedésből fakad. Az ilyen bátorság nem tartós, inkább érzelmek hullámzása, érzelmi megnyilvánulás". ${ }^{9} \mathrm{~A}$ hazaszereteten alapuló bátorság esetében így nem arról van szó, hogy a katona ne érzékelné a veszélyt. Érzékeli a veszélyt, azonban az nem tudatosul benne azon a szinten, hogy irányítsa is a viselkedését. Cselekvéseit ugyanis a hazaszeretet erősebb érzése szabja meg. ${ }^{10}$

Magyarországon nem kapott kiemelkedő figyelmet a hazaszereteten alapuló bátorság, bár nem volt ismeretlen. Kossa Béla Az erkölcsi erélyről című írásában úgy fogalmaz: „az oly sereg, melynek erkölcsi erélye [...] csak magasztos eszmék iránti lelkesedésen alapszik, az a sereg a nélkülözések és veszély közepette illúzióvesztetten csakhamar és könnyedén szétesik"111 Kossa megállapítását érthetjük úgy, hogy a magasztos eszmékre (például a haza és a hazaszeretet) alapozott bátorság is fontos, azonban önmagában nem elegendö, hanem szükség van másra is.

Ezt a másik dolgot Habrovszky Sándor A tisztnek a katonai szellem ápolására való befolyásáról című munkája az istenfélelemben jelöli meg:

Boda Mihály: Az alapvető katonai erények mibenléte és helyük a hosszú 19. századi magyar hadtudományos gondolkodásban. 5. rész. A magyar hadtudományos irodalom. Hadtudomány, 29. (2019), 3. 24-32.

8 Boda Mihály: Az alapvető katonai erények mibenléte és helyük a hosszú 19. századi magyar hadtudományos gondolkodásban. 2. rész. A bátorság. Hadtudomány, 28. (2018a), 2. 18-20.

Carl von Clausewitz: A háborúról. Budapest, Zrínyi Katonai Kiadó, 1961. 76-77.

Boda (2018a): i. m. 25.

Kossa Béla: Az erkölcsi erélyről. Ludovika Akadémia Közlönye, 26. (1899), 557. 
„[...] az istenfélés a katona további erkölcsi nevelésére a legterjedelmesebb alapot képezi. [...] a mindenható istent ismeri és ájtatos alázattal és tiszteletteljes félelemmel hajol meg ama lény előtt, melyet fel nem foghat, de melynek - akaratától tudja hogy életsorsa függ. Ezen egy felsőbb, megfoghatatlan és láthatatlan akaratnak hódoló alárendeltség forrása a sereget éltető folyamnak, a katonai engedelmességnek. A hit elvei az embert feladatainak teljesítésére ösztönzik, az élet viszontagságai között támogatják, bátorságát felélénkítik, a veszélyben megnyugtatják [...]"12

Habrovszky természetesen nem szentháborús ideológiát propagál, hanem arra a legmagasabb értékre (Isten) hívja fel a figyelmet, amely megelőzi a haza és az uralkodó ${ }^{13}$ értékét is. Ennek az értéknek az érzelmi alapon álló tisztelete - az istenfélelem - az, ami a katonában elnyomhatja a veszélyes helyzet okozta félelem érzését.

\subsection{A becsület és a hűség: nemzet és társadalom}

A becsület egy közösség által nagyra tartott érték vagy cselekvésforma melletti kitartás erénye. ${ }^{14} \mathrm{~A}$ hüség a becsület jelentette kitartás egyetlen közösség felé való gyakorlása. ${ }^{15} \mathrm{~A}$ kora újkorban a becsületet a szigorú engedelmességgel végrehajtott tettek eredményezték. Ezeken belül a becsületnek volt eszközértékkel rendelkező formája, amikor a becsület (hírnév) az ellenség és a saját katonák megfélemlítésének (és utóbbi esetben vezetésének) az eszköze. Volt azonban önértékkel rendelkező formája is, amikor a viselkedést a katonai közösség, azaz a többi katona és a katonai vezetők megbecsülték. A becsületnek ezt az utóbbi formáját erkölcsi becsületnek nevezzük. A hüség a kora újkorban az állam vagy a haza szervezete és területe felé mutatott állhatatos kitartást jelentette.

A 19. században a becsület és a hüség erényét tekintve - az olyan, jelentősebb nyugat-európai katonai szerzők, mint Clausewitz és Ardandt Du Picq (1821-1870) munkáiban - csak az erények korábbi formáira találunk direkt hivatkozást. Clausewitz szerint a sokat próbált és győzelemre törő hadseregnek van harci erénye, ami „a pusztító tüzben is megőrzi szokott rendjét [...] és amelyet e kötelességére és erényére egyetlen gondolat: fegyverének becsülete emlékezteti". ${ }^{16}$ Ez a becsület a szigorúan engedelmeskedő hadsereg erkölcsi becsülete. Du Picq pedig még visszább megy az időben. Becsületből való cselekvésnek ugyanis az azokhoz a tettekhez való ragaszkodást hívja, amelyek „az elégséges indok nélkül indított hadjáratok” következményeként állnak

12 Habrovszky Sándor: A tisztnek a katonai szellem ápolására való befolyásáról. Ludovika Akadémia Közlönye, 4. (1877), 144-150, 233-240. 146.

13 Vö. A Szent Szövetség okmánya 1815. szept. 26. In Horváth Jenő (szerk.): Nemzetközi szerződések. Második rész (Anglia és a Szent Szövetség 1815-1848). Budapest, Magyar Külügyi Társaság, 1921. 53-55.

14 Boda Mihály: Az alapvető katonai erények mibenléte és helyük a hosszú 19. századi magyar hadtudományos gondolkodásban. 3. rész. A becsület. Hadtudomány, 28. (2018b), 3-4. 17-30. 17-21.

15 Boda Mihály: Az alapvető katonai erények mibenléte és helyük a hosszú 19. századi magyar hadtudományos gondolkodásban. 4. rész. A hüség. Hadtudomány, 29. (2019a), 1-2. 35-48. 35-39.

16 Clausewitz (1961): i. m. 201. 
elő: értelmetlenek, de „becsületből” mégis végre kell hajtani azokat. A becsületnek ezt a formáját mint idejétmúlt, „nevetséges és hangzatos frázist” Du Picq elveti. ${ }^{17}$

Ezeknek a szerzőknek a hadseregről alkotott képe alapján azonban körvonalazható a becsület és a hüség új típusa is. Clausewitz szerint a háború nem csupán az államokat irányító királyok ügye, hanem az állami politika folytatása más eszközökkel. A politikába azonban beletartozik a külpolitika és a belpolitika is. A belpolitika jelentőségének hangsúlyozását látjuk Clausewitz „csodás hármasságról” alkotott elképzelésében. Eszerint a háborúban nem csupán a (kül)politika irányítói (az „államvezetés”) és a katonák („a hadvezér és a haderö") kapnak szerepet, hanem egy belpolitikai elem, „a hadat viselő nép" is: a "háborút kiváltó szenvedélyeknek már ott kell izzania a nép lelkében"18 Du Picq szerint ahhoz, hogy erős legyen, a tömeghadseregnek racionálisan szervezettnek kell lennie és társadalmi intézménnyé kell válnia. A szervezettség biztosítja a katonák együttmüködését és bajtársiasságát, azaz egymás felé mutatott hűségét. A társadalmi intézményként működő hadsereg fő szervező ereje a csapatszellem (l'esprit de corps), ennek alapja pedig a társadalomban is megtalálható nemzeti érzés. ${ }^{19}$

Clausewitz és Du Picq elképzeléseinek az az alapgondolata, hogy a háború az egész nemzeti társadalom ügye. A katonák tetteinek értéke és hüsége ez alapján az egész nemzeti társadalom vonatkozásában értelmezhető. A becsületet eredményező megbecsültség a nemzeti társadalomért harcoló katonának jár. Ugyanez a katona, ragaszkodva a megbecsültséghez és a nemzeti társadalomhoz, hűséget mutat nem csupán az állam és a haza (szervezete és területe) felé, hanem a nemzeti társadalom felé is. A becsületnek és a hüségnek ezek a formái a közösségi becsület és a közösséghez való hüség. ${ }^{20}$

Magyarországon is találkozhatunk hasonló gondolatokkal. A szigorú engedelmesség és a többi katona megbecsülésének tovább élő jelentősége mellett Magyarországon is fontossá vált a tágabb közösség megbecsülése, illetve a tágabb közösség felé mutatott hüség. Habrovszky a következőképpen vélekedik erről:

„Sohase feledjük, hogy mi tisztek az engedelmesség zászlói vagyunk, és hogy az engedelmességgel becsületünket, nemkülönben a seregét és az államét emeljük."'21

„A fiatal katonának magaviselete annál nagyobb biztonságot nyer, minél jobban halad elő kiképzése, és némi serkentés mellett végre nyilvánuland nála az önbecsülés is [...]. [...] [F]olytatólagos iparkodás neki az elöljárók részéről, tiszteletet, bajtársai részéről pedig tekintélyt szerzend és biztosítand, és hogy ebben becsületét kell keresnie; - hogy a katona, kinek minden perczben készen kell lennie arra, hogy vérét és életét királya és hazája jóllétéért feláldozza a nélkül, hogy ezért jutalmat vagy kitüntetést várna, az államban minden állás között az elsőt foglalja el, s hogy királya és hadura által, ki hasonlóképen egyenruhát visel, kitüntettetik s polgártársai által tiszteltetik. [...]

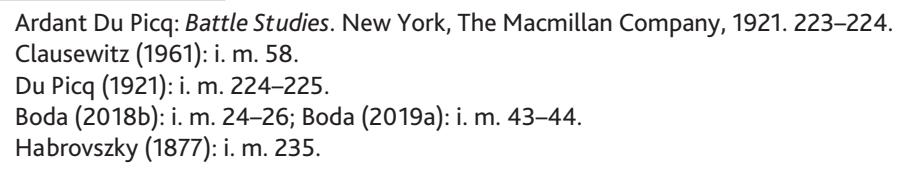


Ha az egyes katonában a becsület- és kötelességérzet felébredt, akkor azt a tiszt a közbecsületre, a »közszellemre« vigye át... A közszellem által minden egyes a maga becsületét az egésznek becsületében leli." ${ }^{\text {22 }}$

"A közszellem azon közös törekvésben áll, hogy az egésznek javát fenntartani és elömozdítani igyekezzünk, és a [...] közszellem soha sem becsli túl magát és másoknak kitünősége által serkentetik. [...]

A kölcsönös tiszteletből, a közös egyenlő kötelességekből és egyenlő törekvésből származik a sereg tagjainak ama fegyvertársi barátságos érzülete, melyet szűk körben bajtársiasságnak szoktunk nevezni."23

„Azonban valamennyi a fenntebbi elemzésben említett katonai erénynek csak a királyunk és a hazánk iránti szeretet és hüség adja meg a szent pecsétet."24

Habrovszky elképzelései részben megegyeznek a nyugati felfogással. Az ő számára is fontos maradt a szigorúan engedelmeskedve szerzett becsület, és mellette megjelent az egyes katonák közötti hüséget meghatározó bajtársiasság, illetve a hadsereghez való hüséget megalapozó közszellem (csapatszellem) is. A közszellem szervezte hadsereg az állam (a „társadalom" értelmében) legfontosabb része, így a katonák nem csupán a hadsereg többi tagjának a megbecsülését érdemlik ki, hanem az állam („társadalom”) minden tagjáét is. Cserébe a katonáknak a hüség erénye által akár az életüket is fel kell áldozniuk a királyért és az államért („társadalomért”).

A hadsereg társadalmi beágyazottságát így Magyarországon is megtaláljuk. Ez azonban a dualista állam felépítésének köszönhetően, ahol nem volt egységes nemzet, nem járt együtt a nép szenvedélyes támogatásának vagy a nemzeti érzésnek a hangsúlyozásával. A beágyazottság csupán az uralkodó vezette dualista államba („társadalomba”) való intézményi beilleszkedést jelentette.

\subsection{A katonai vezetői erény: gondoskodás}

A karizma a döntéshozatalra való alkalmasság és a határozottság erénye az alárendelt katonák vezetése során, a katonai feladat-végrehajtásra jellemző kiszámíthatatlan körülmények között. ${ }^{25} \mathrm{~A}$ kora újkori vezetési erény a szervezés erénye (szervezőképesség), ami által a katonai vezető éppúgy képes megszervezni a rá bízott katonák ellátását, menetét, mint a csatában és a hadjáratban megkívánt manővereiket. A vezető a szervezéssel képes csökkenteni a kiszámíthatatlanságot. ${ }^{26}$

A 19. században, a hadsereg társadalmi integrációjával, a vezetési erény a gondoskodás erényévé vált. A korszak kiemelkedő hadtudósa, Helmuth von Moltke (1800-1891) szerint

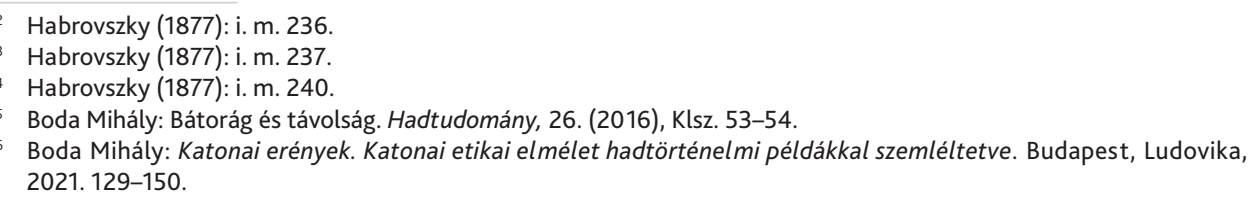




\begin{abstract}
„tisztjeink élete fáradtsággal, nélkülözéssel és önmegtagadással teli élet, amely fizetségét csak saját öntudatában találja meg. A katonához füződő kapcsolatuk viszont olyan szép, hogy soha nem mondanának le róla az altiszti kar javára. A századparancsnok valóban atyja a legénységnek. Minden egyes embere helyzetét pontosan ismeri, ügyel erkölcsi fejlődésére, vezeti a katonai kiképzést, felügyel anyagi ellátására és minden módon gondoskodik róla". ${ }^{27}$
\end{abstract}

Ennek értelmében a hadsereg egy egység, olyan, mint egy nagy család, ${ }^{28}$ ahol a katonai vezetők az „atyák”, a beosztott katonák pedig a „fiúk”. A katonai vezetői erény jelen típusa is erre a „családi” viszonyra épül, amelyben a katonai vezető a szó szorosabb értelmében vezeti a beosztottjait, nem csupán a csatában, hanem a békében is.

A kérdéses viszony alapja az összecsiszolódás a hosszabb együtt eltöltött idő során, a hadsereg és az egység közös értékrendjének égisze alatt, aminek az érvényre juttatásában a katonai vezetőnek nagyobb tapasztalata van, mint a beosztott katonáknak. A tisztnek ezért a békében ügyelnie kell a beosztott katona erkölcsi fejlődésére, vezetnie kell kiképzését, felügyelnie kell anyagi ellátását, és minden módon gondoskodnia kell róla. A tiszt gondoskodó vezetése a beosztott katonákban bizalmat ébreszt. A bizalom kialakulásával pedig a beosztott katonák csatlakoznak a tiszthez, és követik a vezetését. A vezetői gondoskodás a beosztott katona hadseregbeli és a potenciális háborúbeli tevékenységének elvárt keretei között értelmezendő. Nem a katona személyes igényeinek kielégítése vagy „hangulatjavítása” a fő cél, hanem az, hogy jó, a háborúban hatékonyan harcoló katonává váljon.

Moltke szerint azonban a gondoskodás nem jelent mindent ellenőrző felügyeletet is egyben. A kiszámíthatatlanság és a helyzet gyors változása miatt ugyanis sokszor nincs idő arra, hogy a beosztott és elöretolt helyzetben lévő katona jelentést tegyen és megvárja a katonai vezető parancsát. „Ahol az alsó vezetők parancsokra várnak, sohasem fogják a kedvező körülményeket kihasználni. Csak ha valamennyi szintü parancsnokot önálló cselekvésre teszünk képessé, és erre szoktatunk, nyerjük el a lehetőségét annak, hogy nagy tömegeket adott esetben könnyedén mozgassunk."29 A békeidőben megvalósított gondoskodásnak így azt a célt is szolgálnia kell, hogy az alárendeltek képesek legyenek a felmerülő problémák önálló megoldására. Ebben az „alaptételek és általános szempontok” nyújtanak számukra alapot.

Magyarországon a 19. században az uralkodó vezetési stílus a gondoskodásra alapozott vezetés volt. A vezetési stílus egyik fontos propagálója Asbóth Lajos volt, aki $A$ hadvezér és a hadtudomány alapelvei az újabbkori hadjáratok történetével felvilágosítva címú munkájában fogalmazta meg idevonatkozó nézeteit.

Asbóth szerint a katonai célok kivitelezésének legfontosabb eszköze a hadsereg, amelynek anyagi és szellemi erejét is fejleszteni kell. Az anyagi erőknél (fegyvereknél) a szellemi erők fontosabbak. Ezek a hadsereget szabályozó fegyelem és a hadsereg

\footnotetext{
27 Helmuth von Moltke: Hadtudományi írások. In Kocsis Bernát (szerk.): Válogatás burzsoá hadtudományi írásokból. Budapest, Zrínyi, 1985. 365-366.

28 Vö. Ted Wethusing: A Beguiling Military Virtue. Journal of Military Ethics, 2. (2003), 3. 206-207.

29 Moltke (1985): i. m. 364.
} 
egységét biztosító akarat. ${ }^{30}$ Az egységet biztosító akarat a katonai vezető saját akarata, amelyet a hadsereget alkotó katonáknak önszántukból kell elfogadniuk azon az alapon, hogy elismerik a vezető „szellemi tehetségeit”. Ennek az elismerésnek a ténye jelzi, hogy a vezető kiérdemli a sereg "szeretetét, hü ragaszkodását s tiszteletét [...], hogy minden alárendeltje benne nem csak a szigorú parancsnokot, de a gondos atyát is tiszteli". ${ }^{31}$ Az elismerés azt is jelzi, hogy a katonai vezető képes biztosítani a belé vetett bizalmat, amely a „számtalan és soknemü eshetőségek, váratlan körülmények s előre ki nem számítható tényezők mellett" is fennmarad. ${ }^{32}$

Az 1870-1880-as években a Ludovika Akadémia Közlönyének oldalain a témában állást foglaló szerzők pontosították és kidolgozták Asbóth álláspontját. 1877-ben a már korábban is idézett Habrovszky úgy ír, hogy a „tiszt a katona irányában - kötelességszerü gondoskodás mellett - komoly, tetszést nem hajhászó részvétet nyilvánítson". ${ }^{33}$ 1878 második felében az „egy tiszt” néven író szerző négy részből álló tanulmánysorozatot tett közzé $A$ tiszt szolgálati és társadalmi állása feletti élettani elmélkedések (I-IV.) címmel. A szerző hangsúlyozza, hogy a hadsereg egységét biztosító tényező nem közvetlenül a katonai vezető akarata, hanem a közszellem és a bajtársiasság. A közszellem hordozója (a hadsereg „lelke”) a katonai vezető és a tisztikar, amelynek élén „a haza első harczosa”-iként az uralkodó család tagjai állnak. A közszellem által vezetett tisztek a természetes családi kapcsolatokhoz hasonló szellemi rokonságban, speciális családi kapcsolatban állnak egymással. ${ }^{34}$

A közszellemet a tiszteknek az alárendeltekben ápolni kell, mégpedig a kimondott elvárásokon túl a magánéletben nyújtott példával is. A tiszt élete ugyanis, akár a nyilvános, akár a magánélete, példaként szolgál mások számára, a civil társadalom számára is, de főként a beosztott katonák számára. ${ }^{35}$

Ezzel összhangban egy 1880-as anonim tanulmány szerzője szerint „[a] tiszt feladata a hadsorba lépő honpolgárait jó indulattal fogadni és a közös dicső czél felé vezetni, őket valódi honvédőkké nevelni, bennök a hazaszeretetet éleszteni és fenntartani, és oda igyekezni, miszerint ők képesek legyenek és akarják is kötelességüket a golyózáporban és a veszélyek közepette is bátorsággal és áldozatkészséggel teljesíteni". ${ }^{36}$ A tiszteknek az ilyen, szakmailag hatékony, jószándékú és gondoskodó bánásmódja nem azonnal, ám egy idő elteltével biztosan kialakítja a beosztott katonákban a tiszttel szembeni bizalmat, amely által a katona optimista lehet a tiszt szakmai hozzáértése és jószándéka felöl. ${ }^{37}$

A közszellem tartalma a korszakra jellemző katonai erények és erkölcsi értékek voltak. Ezek az erények és értékek a bajtársiasság által mentek át a tisztek és a katonák

\footnotetext{
30 Asbóth Lajos: A hadvezér és a hadtudomány alapelvei az újabbkori hadjáratok történetével felvilágosítva. Pest, Heckenast Gusztáv, 1863. 2.

1 Asbóth (1863): i. m. 9.

32 Asbóth (1863): i. m. 8.

33 Habrovszky (1877): i. m. 235.

34 Egy tiszt: A tiszt szolgálati és társadalmi állása feletti élettani elmélkedések II. Ludovika Akadémia Közlönye, 6. (1878), 10. 713-717; Egy tiszt: A tiszt szolgálati és társadalmi állása feletti élettani elmélkedések IV. Ludovika Akadémia Közlönye, 6. (1878), 12. 867-873.

35 Egy tiszt: A tiszt szolgálati és társadalmi állása feletti élettani elmélkedések I. Ludovika Akadémia Közlönye, 6. (1878), 9. 640; Egy tiszt II. (1878): i. m. 710.

36 Sz. n.: A tiszt. Ludovika Akadémia Közlönye, 8. (1880), 10. 480.

37 Petzrik István: Parancsnok. Magyar Katonai Közlöny, 1. (1908), 1312-1313.
} 
közötti viszonyba. „A tisztikart egy egységes erkölcsi testületté összefüző kötelék idézi elő ama szellemi rokonságot, mely a bajtársiasság fogalma által nyer valódi kifejezést és mely a tisztekre egymás között különös és viszonyos kötelességeket ró." ${ }^{\prime 3} \mathrm{~A}$ bajtársiasság így itt a korábban bemutatottal szemben nem egy alegység integrációját biztosító érték, hanem a hadsereg nagyobb egységeinek az integrációját megalapozó közszellem gyakorlati megvalósulása a tisztek és a katonák között.

A gondoskodás mellett az önállóság biztosítására is találunk példát a korszak magyar hadtudományi írásaiban. Kiss Károly (1793-1866) az 1830-1840-es évek fordulóján a Hadi alapszabályok gyüjteménye és a Hadtudományi Aphorismák címú írásaiban foglalkozott a katonai vezetés önállóságának kérdésével. Kiss szerint a katonai vezető feladata az „egynehány kevés változatlan elveken" ${ }^{39}$ nyugvó stratégiai és taktikai szabályok ismerete, mert csak ezeknek az alkalmazásával győzheti le az „ellenséges fegyver szerencséjét”. ${ }^{40}$ Emellett azonban az is, hogy „semmi kedvező pillanatot hasznavétetlen nem hágy, az esetek »minden változását nyugodtan, és saját tehetségébeni meggyőződésébül eredő, a« legczélirányosabbat mindig megválasztani tudó, és azt végrehajtani is értő bátorsággal, lelki nyugalommal bevárja" ${ }^{41} \mathrm{Ez}$ a kettős feladat Kiss elképzelésében a stratégia és a taktika közötti különbségen, illetve a kettő közötti összefüggésen alapul. Kiss szerint ugyanis minden hadi tevékenység két részre oszlik, a hadi tevékenység céljára, és a cél gyakorlati megvalósítására, azaz a stratégiára és a taktikára. ${ }^{42}$

A kettős feladat ellátásához fontos, hogy a katonai vezető „személyében minél inkább egyesüljenek az akarati és végrehajtási elvek. Minél többet lát ő a saját szemeivel, tesz a saját erejével; minél inkább ura ő hadseregének, függetlenül jutalmaz, és büntet, annál magasabb fokon áll serege fölötti hatalma, annál nagyobb sikerú következményekre tarthat ő számot" ${ }^{43}$ Ennek természetesen az az egyik feltétele, hogy a katonai vezetőnek szabadnak és függetlennek kell lennie. A szabadságot és önállóságot Kiss kétféleképpen is értelmezte, az ellenségtől, és az ellenség parancsnokának a szándékaitól való szabadságként, illetve a hadszíntéren jelen nem lévő saját politikai és katonai vezetők parancsaitól való szabadságként.

Az ellenséggel szembeni szabadság a "stratégiai szabadság”, amelynek az elve abban áll, hogy "hevességtől el ne hagyjuk magunkat ragadtatni, és tegyük mindig az ellenkezőjét annak, mire bennünket az ellenség kényszeríteni látszik". ${ }^{44}$ Ez az elv a hadviselés egyszerü és „változtathatatlan" elvének tünik, ${ }^{45}$ azonban tagadása, és ellentétének elfogadása nem példa nélkül való. A 17. században Montecuccoli úgy vélekedett a kérdésben, hogy a hadviselés általános szabálya az, hogy „az ellenség harcrendje elleni legjobb ellenszer szándékosan azt tenni, amit az ellenség eltervezett.

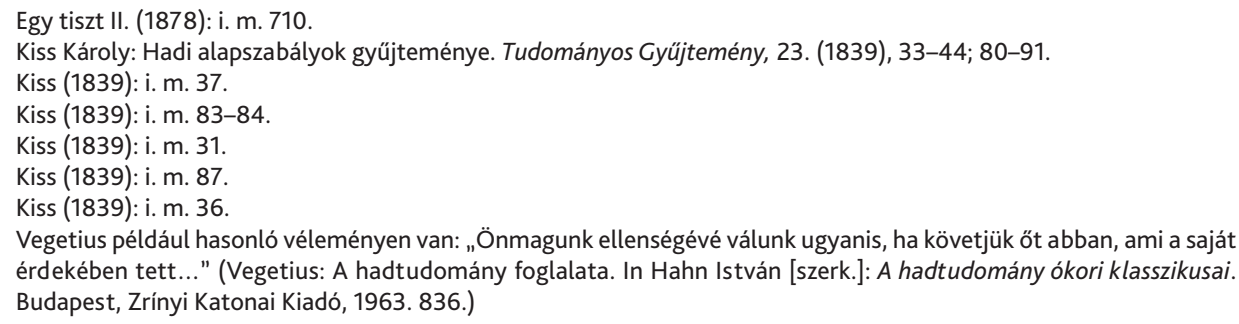
érdekében tett..." (Vegetius: A hadtudomány foglalata. In Hahn István [szerk.]: A hadtudomány ókori klasszikusai. Budapest, Zrínyi Katonai Kiadó, 1963. 836.) 
Mivel bárki alkalmazkodik is a szükségeshez, szándékosan és így rendezetten alávetve magát, azt a saját előnyére, és az ellenség hátrányára teszi". 46

A saját politikai vezetőkkel és katonai felettesekkel szembeni szabadság a katonai vezető függetlensége, ${ }^{47}$ amelynek keretében a katonai vezető a háború természetét és a körülményeket ismerve, ${ }^{48}$ a helyszínen szabadon eldöntheti, hogy milyen cselekvést tart hasznosnak az „egész javára”.

Alárendeltjei tekintetében a katonai vezetőnek főszabály szerint a számukra jelentőséggel rendelkező részleteket kell csak elárulnia a háború folytatásáról, ${ }^{49}$ azonban kivételesen előfordulhat, hogy „az alsóbb hadvezér is magára hagyatva ideiglen függetlenné lesz". Ezekben az esetekben a beosztott katonai vezetőkkel nem szabad "mint gépelyekkel bánni”, hanem célokat kell meghatározni számukra, és parancs helyett a katonai fővezéri szándékot kell tudomásukra hozni. ${ }^{50}$

\subsection{A fegyelmezettség: szocializáció}

A fegyelmezettség a parancsoknak való engedelmeskedés erénye a katonai feladat-végrehajtásra jellemző, kiszámíthatatlan körülmények között. ${ }^{51}$ A fegyelmezettség kora újkori típusa a szigorú engedelmesség volt, ami a kapott parancs szigorú - szó szerinti - végrehajtásában áll.

A 19. században a fegyelmezettség egy új formája került előtérbe, a szocializáción alapuló fegyelmezettség. Moltke szerint a

„fegyelmet [...] nem lehet begyakoroltatni: élménnyé kell válnia. [...] Távolról sem a büntetés az egyetlen eszköz, amivel a fegyelmet fenntarthatjuk. Ehhez odatartozik a katona egész nevelése [...]. Az a nevelés, amit a katona az iskola elvégzése után kap, fontosabb, mint amit ott tanult, azaz a rendszeretet, pontosság, tisztaság, engedelmeség, hűség, röviden a fegyelemhez való szoktatás". 52

A katonai szocializáció eredményeképpen fegyelmezetté váló katonák számára a fegyelmezettség sokkal magától értetődőbb viszonyulás a parancsokhoz és a szabályzathoz, mint a kizárólag esküvel fogadott szigorú engedelmesség esetén. Ennek az az oka, hogy a szocializáció során a katonákban olyan képességek és erények alakulnak ki, illetve a katonák olyan értékeket ismernek meg és tesznek magukévá, amelyek a szocializációval együtt járó belsővé válással (interiorizálódással) támogatják a fegyelmezettségüket. A döntő különbség a szocializációra támaszkodó és a szigorú engedelmeskedésen alapuló fegyelmezettség között a belsővé válásban (interiorizációban), illetve annak hiányában keresendő.

46 Raimondo Montecuccoli: Concerning Battle. In Thomas M. Barker (szerk.): The Military Intellectual and Battle. Albany, State University of New York Press, 1975. 123.

47 Kiss (1839): i. m. 41.

48 Kiss (1839): i. m. 82.

49 Kiss (1839): i. m. 41.

50 Kiss (1839): i. m. 89.

51 Boda (2021) 151-180.

52 Moltke (1985): i. m. 366-367. 
A szocializáció jelen esetben fontos mozzanata abban áll, hogy annak során a katonák olyan értékeket sajátítanak el, amelyeket közösen tisztelnek közvetlen társaikkal, a nagyobb alakulatok tagjaival, és tisztjeikkel együtt. A közös értékek szoros közösséget hoznak létre a szocializációt megelőzően egymáshoz csak lazán kapcsolódó emberekböl, és ezzel biztosítják közöttük a köteléket. A tisztekkel közös értékek elsajátítása azzal jár, hogy a beosztott katonák megbíznak a vezetőjükben, és ezért fegyelmezetten hajtják végre az utasításokat. ${ }^{53} \mathrm{~A}$ fegyelmezettség ebben az esetben abban áll, hogy a katona bízik abban, hogy a katonai vezető megfelelő utasítást ad ki, azaz biztonságban érzi magát a katonai vezető irányítása alatt, vagy optimista - azaz pozitív érzelmi alapállása (attitüdje) van - azt illetően, hogy a katonai vezető utasítása a beosztott irányában jószándékon, a helyzetre vonatkozóan pedig hozzáértésen alapszik. ${ }^{54}$

A 19. századi magyar hadtudományban megtaláljuk a szigorú engedelmességen és a szocializáción alapuló fegyelmezettséget is. A két fegyelmezettségtípus hívei között a 19. század második felében még vita is kibontakozott.

Mészáros Lázár (1796-1858) 1823-ban a katonai kötelességekről szóló, kérdés-felelet formájában megfogalmazott könyvet állított össze százada altisztjei és közhuszárai számára. Ebben a következőképpen fogalmaz: „Miként tartozik fogadni az alattvaló fölebbvalójának parancsát? Az alattvaló szentnek tartson minden parancsot, attól semmi szín, kifogás alatt ne távozzék, s különösen legkisebb ellenmondást se merészeljen." ${ }^{55}$ A század végén, 1895-ben, Báró Wasmer Gusztáv a Huszár kötelesség címü munkájában szintén kérdés-felelet formájában foglalta össze idevonatkozó elképzeléseit. A függelem, fegyelem és fegyelmezettség témakörhöz érve a következőképpen fogalmaz ( $\mathrm{K}=$ kérdés; $\mathrm{F}=$ felelet): „K. Miben áll a függelem? F. Föltétlen engedelmesség melylyel minden katona elöljárójának tartozik. K. Hogy érti ezt? F. Ha egy parancsot kapok ugy azt rögtön és lehető legjobban teljesítsem.." ${ }^{156} \mathrm{Az}$ idézetek azt mutatják, hogy a 19. században fegyelmezettségen értettek szigorú engedelmességet is. A szigorú engedelmesség fontosságát jelzi a meghatározások tartalma, illetve az is, hogy maguk a megfogalmazások is a szigorú engedelmességet megalapozó katonai szabályzatokba illeszkedtek bele.

Az 1870-es évektől azonban, az oktatás és nevelés társadalmi felértékelődésével párhuzamosan, megjelent a katonai szocializáció révén kialakitott fegyelmezettség igénye is. Schnetzer Ferencz vezérkari százados a következőképpen vezeti le ezt az igényt a harceljárás megváltozásából:

„A csata okozta nyomasztó lelki állapotokat csupán a benső erő győzheti le [...]. Ezen erő a hadseregeket összeforrasztó fegyelem.

Ezen fegyelmet a régibb időkben a merev formák közötti vak engedelmességre alapították. [...]

\footnotetext{
Vö. Moltke (1985): i. m. 365; Du Picq (1921): i. m. 115.

54 Vö. Balázs Zoltán: A politikai közösség. Budapest, Osiris, 2003. 64-65; Lawrence C. Becker: Trust as Noncognitive Security and Motives. Ethics, 107. (1996), 1. 46.

55 Mészáros Lázár: Huszárok kézikönyve (részletek). In Dr. Kocsis Bernát (szerk.): Válogatás a magyar hadügy írásaiból. Budapest, Zrínyi, 1986. 461.

56 Báró Wasmer Gusztáv: Huszár kötelesség. H. M. Vásárhely, „Hungária”-könyvnyomda, 1895. 10.
} 
A vonal- és oszlopharcászat ezen időszakában a gyakorlótéri kiképzés egyértelmű volt a harcz végrehajtásával. A harczra képzés tehát igen egyszerű volt. [...]

A szigorú büntetésekkel egybekapcsolt idomítás biztosította a csapattesteken belül a tevékenység egyidejüségét és egyformaságát [...]. A testi cselekvéseknek általa követelt s meg is valósított egyöntetűsége révén kitörölte az egyes harczos lelkéből az egyéniség öntudatát, mert az egyeseknek amiként testükkel ugy lelkükkel is bele kellett olvadniok s eltünniök a zárt tömegben [...].

A modern gyalogsági harcz vivőjévé a rajvonal lett, melynek sajátosságai arra kényszerítették, hogy egész új jelenségeket vegyünk figyelembe [...].

[...] Ezen új általános eszköz a nevelés. A katona lelki tulajdonságainak felébresztése és fejlesztése által a nevelés megteremti azon benső fegyelmet, mely az egyes embert túlsegítette a gyengeség azon pillanatain, melyekben a parancsnok akaratával reá közvetlen befolyást nem gyakorolhat." 57

A szövegből leginkább a nevelés és az idomítás szembeállítását érdemes kiemelni.

A korszak más hadtudományi gondolkodói a katonai nevelést minden további nélkül azonosították az „idomítással”. Például Újhegyi Béla csendőr százados úgy fogalmaz, hogy „míg az ujonczok oktatása, a külön szabályok által irányított módszer alkalmazása mellett, a különféle szabályzatok elméleti és gyakorlati betanítása által eszközöltetik, a katonai nevelés [...] az illetők szellemi valójának kellő átidomításával foglalkozik [...]".58 Bár Újhegyi külön nem hangsúlyozza, feltételezhetjük, hogy az általa elképzelt katonai oktatási és nevelési rendszerben az idomítás, legalább részben, a szabályok elméleti és gyakorlati, büntetéssel szankcionált betanításában áll. Ezzel a katonai nevelésre vonatkozó elképzeléssel helyezkedett szembe Schnetzer, amikor felhíva a figyelmet a háború és a hadseregszervezés jellegének megváltozására, az egyéniséget háttérbe szorító idomítás helyett az egyéniséget előtérbe helyező, szó szerint értett nevelést szorgalmazta. Schnetzer a katonai nevelés fontos megkülönböztető jellegzetességeként tartotta számon - másokkal együtt - a katonák etikai pallérozását. ${ }^{59} \mathrm{Az}$ erkölcsi nevelés a katonák és a hadsereg szellemiségének kialakítását és fenntartását szolgálta.

A nevelés elötérbe kerülésével fontossá vált a katonai vezető és a beosztott katona közötti viszony tisztázása. Domaniczky István őrnagy szerint, amíg az idomítás a beosztottakból önálló akarattal nem rendelkező és gondolkodni nem képes gépeket, ember-automatákat hoz létre, addig a nevelés arra koncentrál, hogy a beosztott katonák bízzanak a katonai vezetőben, ugyanis ezáltal biztosítható az áldozatkészség a harctéren. Ez a bizalom Domaniczky szerint a beosztottnak a katonai vezető hozzáértését és jószándékát illető optimizmusára, illetve a katonai vezető által a beosztottjai felé tanúsított gondoskodásra épül. ${ }^{60}$

Összességében a gyakorlati képzés szempontjából alkalmazandó fegyelmezettségfogalom a korszakban megosztottnak tekinthető. Az ebben a kérdésben egymással szembenálló szerzők azonban egy dologban egyetértettek: mind úgy vélték, hogy

57 Schnetzer Ferencz: Nevelés, iskolázás, szoktató gyakorlás és idomítás. Ludovika Akadémia Közlönye, 32. (1904), 359-360.

58 Újhegyi Béla: A fegyelem és a függelem. Ludovika Akadémia Közlönye, 7. (1879), 5. 392.

59 Schnetzer (1904): i. m. 361; Geiszner Károly: Katonai elmélkedések és észrevételek. Ludovika Akadémia Közlönye, 4. (1876), 4. 331.

60 Domaniczky István: Idomítás vagy nevelés. Ludovika Akadémia Közlönye, 11. (1883), 12. 973; 980. 
a fegyelmezettséget a hadsereget átitató társadalmi kapcsolatokra kell alapozni. A fegyelmezettség szigorú, engedelmességformáját képviselö Újhegyi szerint a katonák esküvel fogadják a parancsoknak és a törvényeknek való engedelmeskedést. Mivel azonban a parancsok a legföbb hadúrtól, vagyis az uralkodótól, a törvények pedig részben az uralkodótól származnak, ezért a katonák végeredményben éppúgy az uralkodónak tartoznak szigorú engedelmességgel, „mint bármilyen rendi állású állampolgár". ${ }^{61}$ Végkövetkeztetését tekintve ezzel összhangban áll a katonai szocializációelmélet hívének, Geiszner Károlynak a véleménye is. Geiszner szerint az erkölcsi nevelés része, hogy a katonák a szolgálatot „magasztos és szép hivatásnak tekintsék, mely kötelességökké teszi a hazának szolgálni és magukat az uralkodó akaratának alávetni". ${ }^{2}$ Ebben az értelmezésben a hazához való hüségnek az erkölcsi nevelés eredményeképpen felerősített eszményével összefüggésben lehet az uralkodóhoz füződő társadalmi kapcsolatokra helyezni a fegyelmezettség hangsúlyát. Így akár a szoktatással kialakított szigorú engedelmesség (a parancsoknak és a törvényeknek), akár az erkölcsi nevelés és katonai szocializáció által felerősített hazához való hűség alapozza is meg a fegyelmezettséget, a 19. század végi Magyarországon az uralkodóhoz füző közösségi/társadalmi kapcsolatokra történő hivatkozást nem lehetett elkerülni.

\section{4. Összefoglalás}

A tanulmány minden hadsereg nélkülözhetetlen katonai erényeinek (a bátorság, a becsület, a hüség, a fegyelmezettség és a katonai vezetői erény) 19. századi formájával foglalkozik. Ebben a korszakban a hadseregek a bürokratikus államok zsoldos hadseregeiből a nemzetállamok (vagy inkább nemzeti birodalmak) állandó tömeghadseregévé váltak. A változás legfontosabb jellemzője Nyugat-Európában a hadsereg társadalmi integrációja, illetve a hadsereg nemzetivé tétele volt. Magyarországra mint az Osztrák-Magyar Monarchia részére - lévén a Monarchia többnemzetiségű politikai entitás volt - ezzel szemben csak a társadalmi integráció volt a jellemző, jelentősebb nemzeti felhangok nélkül.

A hadsereg és a társadalom viszonyának megváltozásával együtt alakultak át a hadsereg katonáival szemben támasztott erkölcsi elvárások, erények is. NyugatEurópában a kora újkorra jellemző mesterséges bátorságot, erkölcsi becsületet, államhoz és hazához való hűséget, szervezésre támaszkodó vezetést és a szigorú engedelmességgel összekötöttt fegyelmezettséget a 19. században felváltotta a hazaszeretetre épülő bátorság, a tágabb közösségi becsület, a társadalom felé mutatott hűség, a gondoskodáson alapuló vezetés és a szocializáción nyugvó fegyelmezettség.

A hadsereg integrációjában jelentkező magyar sajátosságok az erények esetében is fennálltak. Így a nemzeti társadalomba való integráció helyett az Istent képviselő uralkodó (aki egyben a legföbb katona is volt) által vezetett társadalomba történő betagozódás került előtérbe az erények tartalmának meghatározásakor. A bátorság tekintetében ezért a hazaszeretet nem kapott nagy hangsúlyt, hanem helyette inkább az istenfélelem és az elöljáró (az uralkodó) tisztelete került a középpontba. A becsület esetében fontos

61 Újhegyi (1879): i. m. 381-383.

62 Geiszner (1876): i. m. 334. 
megbecsülés a tágabb közösségből érkezett, amiként a katona hüséggel is a tágabb közösség felé tartozott. A tágabb közösség legfontosabb jellemzője azonban az uralkodó személye volt. A becsület így valójában az uralkodó általi megbecsülésből származhatott, a hüségnek pedig az uralkodó felé kellett irányulnia. Ebben azonban a katonák a társadalom elé állított mintát jelentettek. A vezetői erény és a fegyelmezettség esetében nagyobb egyezés mutatható ki a magyar és a nyugati szakírók véleménye között. Mindkét félnél a gondoskodás volt a vezetői erény (ami megengedi az önálló feladatvégrehajtást is), illetve a szocializációra épülő engedelmesség a fegyelmezettség új formája. Mivel azonban mind a gondoskodás, mind a szocializáció és az azzal kapcsolatban kialakított bizalom esetében központi szerepe volt a társadalmi értékrendszernek, így ezek az erények is inkább az uralkodót helyezték a középpontba. Összességében az mondható el, hogy a dualista periódus „Isten-király-haza" katonai szentháromsága (amely a társadalom felől nézve „szentnégyességgé”, azaz „Isten-király-haza-hadsereg”-gé bővült) alapjaiban határozta meg a korszak katonai erényeinek tartalmát, és különböztette meg azokat a hasonló erények nyugat-európai értelmezésétől.

\section{Felhasznált irodalom}

Asbóth Lajos: A hadvezér és a hadtudomány alapelvei az újabbkori hadjáratok történetével felvilágosítva. Pest, Heckenast Gusztáv, 1863.

A Szent Szövetség okmánya 1815. szept. 26. In Horváth Jenő (szerk.): Nemzetközi szerződések. Második rész (Anglia és a Szent Szövetség 1815-1848). Budapest, Magyar Külügyi Társaság, 1921. 53-55.

A tiszt. In Ludovika Akadémia Közlönye, 8. (1880), 10.

Balázs Zoltán: A politikai közösség. Budapest, Osiris, 2003.

Báró Wasmer Gusztáv: Huszár kötelesség. H. M. Vásárhely, A „Hungária” könyvnyomda nyomása, 1895.

Becker, Lawrence C.: Trust as Noncognitive Security and Motives. Ethics, 107. (1996), 1. 43-61. Online: https://doi.org/10.1086/233696

Boda Mihály: Az akarattól a tettig. A parancsteljesítés erkölcsi indokai. Hadtudomány, 26. (2016), 3-4. 16-28. Online: https://doi.org/10.17047/HADTUD.2016.26.3-4.16

Boda Mihály: Bátorág és távolság. Hadtudomány, 26. (2016), Különszám. 44-58. Online: https://doi.org/10.17047/HADTUD.2016.26.K.44

Boda Mihály: Az alapvető katonai erények mibenléte és helyük a hosszú 19. századi magyar hadtudományos gondolkodásban. 1. rész. Az erények és a katonai erénylisták. Hadtudomány, 28. (2018), 1. 38-47. Online: https://doi.org/10.17047/ HADTUD.2018.28.1.38

Boda Mihály: Az alapvető katonai erények mibenléte és helyük a hosszú 19. századi magyar hadtudományos gondolkodásban. 2. rész. A bátorság. Hadtudomány, 28. (2018), 2. 18-29. Online: https://doi.org/10.17047/HADTUD.2018.28.2.18

Boda Mihály: Az alapvető katonai erények mibenléte és helyük a hosszú 19. századi magyar hadtudományos gondolkodásban. 3. rész. A becsület. Hadtudomány, 28. (2018), 3-4. 17-30. Online: https://doi.org/10.17047/HADTUD.2018.28.3-4.17 
Boda Mihály: A hivatás és a katonai hivatás története és elemei. Hadtudomány, 28. (2018), 3-4. 135-155. Online: https://doi.org/10.17047/HADTUD.2018.28.3-4.135

Boda Mihály: Az alapvető katonai erények mibenléte és helyük a hosszú 19. századi magyar hadtudományos gondolkodásban. 4. rész. A hüség. Hadtudomány, 29. (2019), 1-2. 35-48. Online: https://doi.org/10.17047/HADTUD.2019.29.1-2.35

Boda Mihály: Az alapvető katonai erények mibenléte és helyük a hosszú 19. századi magyar hadtudományos gondolkodásban. 5. rész. A magyar hadtudományos irodalom. Hadtudomány, 29. (2019), 3. 24-32. Online: https://doi.org/10.17047/ HADTUD.2019.29.3.24

Boda Mihály: Katonai erények. Katonai etikai elmélet hadtörténelmi példákkal szemléltetve. Budapest, Ludovika Egyetemi Kiadó, 2021.

Boda Mihály: A katonai erények paradigmaváltása a késő középkor és a kora újkor között. Hadtörténelmi Közlemények, 134. (2021), 3. 613-637.

Clausewitz, Carl von: A háborúról. I. könyv. Budapest, Zrínyi, 1961.

Domaniczky István: Idomítás vagy nevelés. Ludovika Akadémia Közlönye, 11. (1883), 12. 963-985.

Du Picq, Ardant: Battle Studies. New York, The Macmillan Company, 1921.

Egy tiszt: A tiszt szolgálati és társadalmi állása feletti élettani elmélkedések I. Ludovika Akadémia Közlönye, 6. (1878), 9. 637-650.

Egy tiszt: A tiszt szolgálati és társadalmi állása feletti élettani elmélkedések II. Ludovika Akadémia Közlönye, 6. (1878), 10. 709-717.

Egy tiszt: A tiszt szolgálati és társadalmi állása feletti élettani elmélkedések IV. Ludovika Akadémia Közlönye, 6. (1878), 12. 862-874.

Geiszner Károly: Katonai elmélkedések és észrevételek. Ludovika Akadémia Közlönye, 4. (1876), 4. 323-335.

Kiss Károly: Hadi alapszabályok gyűjteménye. Tudományos Gyüjtemény, 23. (1839), 33-44, 80-91.

Kövér Tibor - Gyáni Gábor: Magyarország társadalomtörténete a reformkortól a második világháborúig. Budapest, Osiris, 2006.

Mészáros Lázár: Huszárok kézikönyve (részletek). In Kocsis Bernát (szerk.): Válogatás a magyar hadügy írásaiból. Budapest, Zrínyi, 1986. 459-485.

Moltke, Helmuth von: Hadtudományi írások (részletek). In Kocsis Bernát (szerk.): Válogatás burzsoá hadtudományi írásokból. Budapest, Zrínyi, 1985. 331-384.

Montecuccoli, Raimondo: Concerning Battle. In Thomas M. Barker (szerk.): The Military Intellectual and Battle. Albany, State University of New York Press, 1975. 73-173.

Petzrik István: Parancsnok. Magyar Katonai Közlöny, 1. (1908), 1309-1316.

Schnetzer Ferencz: Nevelés, iskolázás, szoktató gyakorlás és idomítás. Ludovika Akadémia Közlönye, 4. (1876), 4. 323-335.

Újhegyi Béla: A fegyelem és a függelem. Ludovika Akadémia Közlönye, 7. (1879), 5. 381-395.

Vegetius: A hadtudomány foglalata. In Hahn István (szerk.): A hadtudomány ókori klasszikusai. Budapest, Zrínyi, 1963. 751-866.

Wethusing, Ted: A Beguiling Military Virtue. Journal Of Military Ethics, 2. (2003), 3. 195-212. Online: https://doi.org/10.1080/15027570310004186 